NBER WORKING PAPER SERIES

CHINESE FIRM AND INDUSTRY REACTIONS TO ANTIDUMPING INITIATIONS AND MEASURES

\author{
Chunding Li \\ John Whalley \\ Working Paper 16446 \\ http://www.nber.org/papers/w16446
NATIONAL BUREAU OF ECONOMIC RESEARCH
1050 Massachusetts Avenue
Cambridge, MA 02138
October 2010

We are grateful to the Ontario Research Fund for financial support, and to a seminar group at UWO, Chad P. Bown and Xing Chunbing for comments and discussions. The views expressed herein are those of the authors and do not necessarily reflect the views of the National Bureau of Economic Research.

NBER working papers are circulated for discussion and comment purposes. They have not been peerreviewed or been subject to the review by the NBER Board of Directors that accompanies official NBER publications.

(C) 2010 by Chunding Li and John Whalley. All rights reserved. Short sections of text, not to exceed two paragraphs, may be quoted without explicit permission provided that full credit, including (C notice, is given to the source. 
Chinese Firm and Industry Reactions to Antidumping Initiations and Measures

Chunding Li and John Whalley

NBER Working Paper No. 16446

October 2010

JEL No. F1,F10

\begin{abstract}
$\underline{\text { ABSTRACT }}$
Because of large and rapid growing export volumes and its formal status as a non-market economy; China has been the subject of large numbers of both antidumping initiations and measures. Current estimates are that around $40 \%$ of such actions are against China; India, in turn, is the largest source of initiation against China by number of actions. Here we explore the reactions of Chinese firms and industries to these actions. No other papers to our knowledge explore these reactions empirically. We use industrial panel data on all Chinese firms in the industry, foreign firms operating within China and state owned enterprises (SOE) for aggregated firms group between 1997 and 2007. This provides information on sales, profits, firm numbers, labor productivity, and employment. We are able to link this data with a World Bank dataset on antidumping actions by industry by country (both by and against) for the same period. We then use a dynamic system GMM estimator to explore the importance of different forms of Chinese firms' overall response to both initiations and measures. We also separately analyze antidumping actions against China from developed and developing countries, US and EU to compare their different effects. We find that antidumping actions by developed and developing countries negatively impact industrial profits and employee and firm numbers and also exports. Output impacts are the smallest. Labor productivity is improved by antidumping actions. We also find that different kinds of firms show different responses. All firms together in an industry react to antidumping the most, and foreign and SOE firms show a much smaller response. Also, developed countries' antidumping actions have more negative impact than developing countries' actions for all firms and SOEs, but foreign firms' impacts are the opposite. Chinese industry reactions to antidumping actions by the US and EU are the same as for other developed countries, but the effects of US actions are larger. US antidumping actions have more impact than EU's on firm numbers, employees and exports, and EU antidumping has more influence than US on output, profit and labor productivity. Finally, comparing Chinese, foreign, and SOE firm's reactions to US and EU antidumping actions, our results show foreign firms to be hurt more by antidumping from EU. We discuss policy implications in a concluding section.
\end{abstract}

Chunding Li

Institute of World Economics and Politics

Chinese Academy of Social Sciences

No.5 Jianguomenneidajie

Beijing, PRC

Postcode: 100732

cli428@uwo.ca

John Whalley

Department of Economics

Social Science Centre

University of Western Ontario

London, Ontario N6A 5C2 CANADA

and NBER

jwhalley@uwo.ca 


\title{
Chinese Firm and Industry Reactions to Antidumping Initiations and Measures
}

\begin{abstract}
Because of large and rapid growing export volumes and its formal status as a non-market economy; China has been the subject of large numbers of both antidumping initiations and measures. Current estimates are that around $40 \%$ of such actions are against China; India, in turn, is the largest source of initiation against China by number of actions. Here we explore the reactions of Chinese firms and industries to these actions. No other papers to our knowledge explore these reactions empirically. We use industrial panel data on all Chinese firms in the industry, foreign firms operating within China and state owned enterprises (SOE) for aggregated firms group between 1997 and 2007. This provides information on sales, profits, firm numbers, labor productivity, and employment. We are able to link this data with a World Bank dataset on antidumping actions by industry by country (both by and against) for the same period. We then use a dynamic system GMM estimator to explore the importance of different forms of Chinese firms' overall response to both initiations and measures. We also separately analyze antidumping actions against China from developed and developing countries, US and EU to compare their different effects. We find that antidumping actions by developed and developing countries negatively impact industrial profits and employee and firm numbers and also exports. Output impacts are the smallest. Labor productivity is improved by antidumping actions. We also find that different kinds of firms show different responses. All firms together in an industry react to antidumping the most, and foreign and SOE firms show a much smaller response. Also, developed countries' antidumping actions have more negative impact than developing countries' actions for all firms and SOEs, but foreign firms' impacts are the opposite. Chinese industry reactions to antidumping actions by the US and EU are the same as for other developed countries, but the effects of US actions are larger. US antidumping actions have more impact than EU's on firm numbers, employees and exports, and EU antidumping has more influence than US on output, profit and labor productivity. Finally, comparing Chinese, foreign, and SOE firm's reactions to US and EU antidumping actions, our results show foreign firms to be hurt more by antidumping from EU. We discuss policy implications in a concluding section.
\end{abstract}

Keywords: Antidumping; Industry Reactions; China; Industry Level Panel 


\section{Introduction}

In this paper, we discuss firm and industry responses in China to antidumping (AD) initiations and measures. As China's exports have grown, so along with them have trade actions against China through antidumping duties. In the last decades, China was the largest $\mathrm{AD}$ initiation and measure recipient country in the world. There are a lot of reasons why China is a prime target for those AD measures. One is China's rapid export growth and the adjustment pressures these create in foreign markets. Another is China's non-market economy (NME) status $^{1}$ in key countries (US and EU especially), relatively ineffective legal defenses, and the low concentration ratio in many Chinese industries which makes industry coordination to resist these measures more difficult.

China's NME status is a reflection of its accession terms to the WTO. In 2001, China agreed that it be treated as a NME for 15-years to 2016 (Chen, 2009). As a result petitioners do not have to use Chinese domestic input prices in determining the cost of the production of an investigated product. This has been part of the reason for the growth in antidumping initiations against China since the low cost of labor is the major source of comparative advantage in trade for China. China's non-market status also grants greater discretionary power to initiators which again increased the frequency of AD measures.

When faced with an antidumping measure, a Chinese industry or the firm may react in various ways. These may include refocusing production on domestic markets, increased exports to other countries, or location abroad. Another is producing something else to avoid the foreign trade barriers. Fighting

\footnotetext{
1 There are 10 NMEs at present: China, Ukraine, Kazakhstan, Vietnam, Albania, Armenia, Georgia, Kyrgyzstan, Moldova and Mongolia. Russia was granted market status in 2000, while Vietnam's request for MES has been considered and rejected.
} 
the action and trying to solve the dispute by reaching agreement on a price undertaking is also an option. The final option is to close down production and exit the market.

The reaction of Chinese firms and industries to these antidumping actions is now an important element in the policy debate in China as it affects what to do in response. If firms can easily adapt by producing different products and maintain profits and employment, active response seems less of an issue than if they are severely impacted. Therefore, analysis of the effects of antidumping actions on Chinese firms as industry groups is central to this debate.

Specifically, we build all firm summed industry and other two kinds of firm summed (foreign firm and state-owned firm) ${ }^{2}$ industrial division group panel data sets covering 39 industries from 1997 to 2007 for use in our analysis. We separate out $\mathrm{AD}$ actions into those undertaken by developed and developing countries, and also divide AD actions between the United States (US) and the European Union (EU). We exam their different effects on exports, output, profit, total firm number, total employee and industry labor productivity. The results allow us to assess both Chinese industries' and firm groups' reactions. Our regression method involves system Generalized Method of Moments (GMM) estimator (Arellano and Bover, 1995; Blundell and Bond, 1998).

In the next section we discuss Chinese $\mathrm{AD}$ experience and offer a brief literature review. Section 3 is data description and methodology. Section 4 reports and discusses empirical results. The final section concludes and discusses policy implications.

\footnotetext{
${ }^{2}$ It is important to also analyze private firm group reactions, but because of data availability, we can only obtain three years of this group data which are not enough for regression analysis, so their reactions can just be deduced indirectly.
} 


\section{Chinese Experience with AD and Prior Literature on the Impacts of $\mathrm{AD}$}

According to the WTO antidumping database (WTO, 2010), China was the recipient of $19.75 \%$ of 3427 worldwide antidumping initiations and $21.87 \%$ of 2190 antidumping measures globally between 1995 and 2008. In the last three years, 2006-2008, China was the recipient of 72, 61 and 73 AD initiations and 37, 48, $52 \mathrm{AD}$ measures respectively. These account for nearly $40 \%$ of the world totals (Fig. 1). Compared with China's total exports, the export value of AD initiations and measures is not nearly as high since the product coverage of actions is usually narrowly focused. Per unit export coverage of AD measures in India and Korea are higher than in China (Fig. 2), but in the top ten AD measure receivers in the period 1995-2008 China ranks first (Table 1). China's main AD initiator complaint countries are India, US, EU, Argentina, Turkey and Brazil (Table 2).

[Fig. 1- Fig. 2 around Here]

[Table 1- Table 2 around Here]

A significant theoretical and empirical literature devotes exists on the impacts of $\mathrm{AD}$ measures, but does not discuss the Chinese case. Most papers focus on trade effects and reactions of AD by firms and industries, and find that $\mathrm{AD}$ have both trade depression and trade diversion effects. This literature includes Staiger and Wolack (1994), Prusa (2001), Ganguli (2005), Baylis et al (2009), Carter and Trant (2010). Some literature has also explored export or import countries' reactions to AD in other dimensions; for example technological innovation, market power, and pricing etc (Crowley, 2006; Konings and Vandenbussche, 2005; Duc, 2010). 
As heterogeneous firm trade theory has evolved in recent years, recent papers have also studied AD effects in this theoretical framework. These papers mainly analyze firms' productivity response to AD protection, and include Konings and Vandenbussche (2008a), Konings and Vandenbussche (2008b) and Pierce (2009). There is also some literature analyzing AD effects in other ways. Brown (2005) uses a specific case study to examine the response of Korean steel firms after being assessed AD duties in the US. Francois (2009) sets up a global simulation model for analysis of tariffs and AD policy impacts on price, output, income and employment.

Literature on China largely analyzes the reasons for $\mathrm{AD}$ and does not empirically analyze AD impacts on Chinese industry or firms. McGee and Yoon (1998) use five AD action cases initiated by US against China to assess development impacts. Messerlin (2004) analyzes both China's antidumping recipient and user characteristics. Chu and Prusa (2004) study the reasons for and the impact of AD on China. Park (2009) studies Chinese trade diversion effects of $\mathrm{AD}$ actions. His results show that $\mathrm{AD}$ protection has both significant trade depression and trade diversion effects. Bown and Crowley (2010) analyze US and EU AD duties impacts on China's export; findings that trade depression effects are weak and trade deflection effects are significant. 


\section{Methodology and Data}

In this paper we explicitly study China's industry and firm group reactions to $\mathrm{AD}$. We separately compare effects of $\mathrm{AD}$ from developed and developing countries on Chinese industries, and in addition separately analyze the US and the EU. We use system GMM methods to obtain results.

\subsection{Methodology}

We use panel data regression to analyze AD effects on Chinese industry and firm groups. Affirmative and negative measures have different effects. Additionally, AD can have lag effects. We use an estimation equation (1) where $\mathrm{Y}_{\mathrm{i}, \mathrm{t}}$ denotes the dependent variable.

$$
\begin{gathered}
\ln \left(Y_{i, t}\right)=\alpha+\beta_{1} \ln \left(Y_{i, t-1}\right)+\beta_{2} A D_{\mathrm{i}, \mathrm{t}-1}+\beta_{3} A D_{i, t}+\beta_{4} A D 1_{\mathrm{i}, \mathrm{t}-1} \\
+\beta_{5} A D 1_{\mathrm{i}, \mathrm{t}}+\beta_{6} A D 2_{\mathrm{i}, \mathrm{t}}+\beta_{7} A D 3_{\mathrm{i}, \mathrm{t}}+\beta_{8} A D 4_{\mathrm{i}, \mathrm{t}}+ \\
\beta_{9} A D 1_{\mathrm{i}, \mathrm{t}} * A D 2_{\mathrm{i}, \mathrm{t}}+\beta_{10} A D 1_{\mathrm{i}, \mathrm{t}} * A D 3_{\mathrm{i}, \mathrm{t}}+ \\
\beta_{11} A D 1_{\mathrm{i}, \mathrm{t}} * A D 4_{\mathrm{i}, \mathrm{t}}+\beta_{12} \text { Time }+\varepsilon_{i}+v_{\mathrm{i}, \mathrm{t}}
\end{gathered}
$$

In our regressions we specifically consider industry exports, output, firm numbers, profits, and employee and labor productivity as endogenous variables. $Y_{i, t-1}$ are one year lag effects of dependent variables. $\mathrm{AD}_{\mathrm{i}, \mathrm{t}-1}$ and $\mathrm{AD} 1_{\mathrm{i}, \mathrm{t}-1}$ are separately one year lag terms of $\mathrm{AD}_{\mathrm{i}, \mathrm{t}}$ and $\mathrm{AD} 1_{\mathrm{i}, \mathrm{t}}$. In order to control for long term trend effects, we add a time trend variable in the equation. In dependent variables, labor productivity equals added value divided by numbers of employees. We use logarithmic values in our regressions to simplify the results and reduce heteroscedasticity. Table 3 summarizes these variables.

[Table 3 around Here]

We use a general-to-specific method to determine the lag length numbers for dependent and independent variables (Hendry and Clements, 2004) ${ }^{3}$. Our data

\footnotetext{
3 For dynamic time series data, we can use an AIC and BIC rule to determine lag numbers. But there are no such rules for panel data. Here in the general-to-specific method developed by Hendry and Clements, the specific rule is first select a large lag order in the regression, if the coefficient is significant keep it, if not drop.
} 
embodies autocorrelation with one lag and so we include one lag in the right-hand side of our empirical specification. Because of lags in our dependent variable, we use dynamic panel methodology to estimate our equations. We deploy the Arellano-Bond instrumental variable procedure (Arellano and Bover, 1995; Blundell and Bond, 1998) and which proposes a GMM estimator which accounts for within-panel autocorrelation and heteroskedasticity and estimates a dynamic panel specification similar to equation (1) above.

The dynamic panel estimator first put forward by Arellano and Bond (1991) as a first order difference GMM produces estimates after taking first order differences in order to eliminate individual effects. Such methods however can induce sample partial bias (Blundell and Bond, 1998). Blundell and Bond (1998) propose a GMM-system estimator which not only first order differences but also uses lagged difference variables as instrumental variables to construct level equations. This method avoids endogeneity problems. This GMM estimator can be divided into one step and two step forms; the two step GMM method can give more robust results (Arellano and Bond, 1991; Windmeijer, 2005). Regressions in our paper are all two step system GMM results of this form.

\subsection{Data}

We use three data samples; an all firm summed industry sample, a foreign firm summed group sample, and a state-owned firm summed group sample. These data are firm summed within industries, and not firms by firm. Each sample yields observations of 39 industries from 1997 to 2007. Tables 4 and 5 give the overall summary statistics of the dependent and independent variables in the empirical analysis.

[Tables 4-5 around Here] 
Data on dependent variables except export values come from the Chinese Statistical Yearbook, and we use producer price indices as deflators. Export value data come from the Chinese Customs Statistical Yearbook. The AD data come from a World Bank global AD database (Bown, 2010). All of the dependent variables except export values are classified by Chinese "National Economy Industrial Classification" (NEIC) and have 39 2-digital manufacturing industries. The independent variables and export values are classified by the Harmonized System Codes Commodity Classification (HS). They cannot be directly merged together by industry. We take the NEIC as our benchmark; and allocate all of the AD cases into NEIC industries according to the detailed AD products as named one by one. We only have all firm summed industry data for export values.

The global AD database (Bown, 2010) provides detailed AD case information by country division. Because our data are firm summed by industry, we cannot include $\mathrm{AD}$ duty variables in our regressions because most cases involve specific firms. Independent variables in our regressions are thus all dummies. Hence, if one or more firm in an industry received an AD investigation or measure in one year, we take that year's AD investigation or measure variable to equal 1 , otherwise it equals 0 . 


\section{Empirical Results}

This section reports our empirical results. Since AD measures from developed and developing countries may have different effects, we first explore Chinese industry and firm group reactions with added discrimination among AD actions by developed and developing countries. Since the US and the EU are the two main trading partners of China, it is useful to also analyze and compare their separate AD effects.

The global AD database (Bown, 2010) only has main countries' AD information. We take the US and the EU to jointly denote developed countries (these two countries account for more than $25 \%$ of China's total received AD initiations and measures (WTO, 2010)); and Argentina, India, Brazil, and Turkey as developing countries (these four countries account for about $40 \%$ of China's total received AD initiations and measures (WTO, 2010)).

\subsection{Impacts of AD from Developed and Developing Countries on Total} Firm Numbers, Output, Employee, Profit, Labor Productivity and Exports

Tables 6 to 7 report our estimation results. AD from both developed countries and developing countries adversely affect industry and firm groups' output, employee, profit, firm numbers, and exports, but improve labor productivity. Comparatively, profits are hurt the most; the next are employees, firm numbers, and exports, and output is impacted the least. This suggests that when facing an $\mathrm{AD}$ measure, firms decrease their prices and profits, and then reduce employment to lower costs, but try to maintain exports and output. Different kinds of firms also show different kinds of response to AD measures. All firm summed industry react the most. Foreign and SOE firm groups show a small reaction. This suggests that AD mainly influences private firms. 
Developed countries' AD have greater negative effects than developing countries' on all firm summed industry and SOE firm groups. But the foreign firm group is impacted more by developing countries' AD. This may because most foreign firms in China are from developed countries and they can avoid impacts easily by intra-firm trade adjustments.

AD measures have generally significant effects on firm numbers. Also, variables related to one year before an investigation or the year of investigation and measure all have significant positive effects on all firms summed industry, and developed countries' ADs have more influence. This suggests that firms enter the market and increase export before $\mathrm{AD}$ investigation and measures which directly induced other countries' AD countermeasure. Variables of one year after measure, one year after if more than one investigation and interaction term of one year after if affirmative in developed countries and one year after if affirmative in developing countries also have significant negative effects using all firm summed industry data. The developed countries' AD influence is more pronounced than for developing countries. Foreign firms and SOE firms response is less. Only variables of one year after if more than one investigation and the cross term of one year after if affirmative have negative effects. SOE firms show no significant influence for measures. In our data sample, all firms include SOE, foreign and private firms, so these results suggest that private firms responded more in firm numbers.

For Chinese industrial output reaction, variables of one year after measure and interaction terms of one year after if affirmative and one year after if more than one investigation all have negative impacts on all firm industry output. Developed countries' ADs again have more impact. Variables of year of 
investigation, measure and before measure in both developed and developing countries all have positive effects on all firm output. Foreign firm output has little reaction which may suggest that firms can easily circumvent AD barriers. SOE firm output shows little response; most of the reaction is by private firms. Since continuously increasing output may be one of the reasons for AD to China, these AD investigations and measures may exhibit simultaneity bias in our regressions.

Chinese industrial employee reaction also shows significant coefficients only one year after an affirmative decision in developed countries and is significantly negative for all firm employees. This suggests that all firm employees only respond to developed countries' affirmative AD measures. Variables of year of investigation in developing countries and one year before investigation in both developed and developing countries have positive relationships with all firm employees. One year after if affirmative and interaction term of one year after if more than one investigation in developed countries have large negative impacts on foreign firm employees. Also, variables of one year after if affirmative, one year after if more than one investigation from developing countries have negative impacts on foreign firm employees. Foreign firm employee numbers seem more sensitive to AD measures, which may because foreign firms are more flexible to change their workers. SOE firm employee numbers have little reaction to both developed and developing countries' AD.

Chinese industrial profit reactions suggest developed countries' variables of year of investigation, year of measures, one year after measures and one year after if more than one investigation are all negatively related with all firm profits. Developing countries' influences here are prominently weak. Developing 
countries' variables of one year before and year of investigation and year of measure are all positively related to all firm profits. Total foreign firm profits are negatively influenced by $\mathrm{AD}$ measures from developing countries. Although AD measures have little impact on exports and output of foreign firms, they impact their profit significantly. AD has little impact on the profit of SOE firms.

As for as Chinese industrial labor productivity reaction is concerned, developed countries' AD investigations and measures have little effect on all firm industrial labor productivity, only the variable of one year before investigation is significantly positive. Developing countries' AD variables are positively related with labor productivity with large coefficients. This suggests that AD threats have incentive effects on industrial labor productivity. Labor productivity improvement for foreign firm summation industry is more than for all firms. Foreign firms' larger labor productivity improvement may reflect the larger negative impact on employees than on output. In contrast, SOE firms' industrial labor productivity has virtually no response, but the variable of one year before investigation has a negative influence, perhaps because SOE firms find it harder to adjust employees in the short run when facing an $\mathrm{AD}$ threat.

Finally comes Chinese industrial export reactions. We only have all firm summation industrial data on exports. Both developed and developing countries' ADs have a negative influence on industrial exports, especially the variables of year of measure and one year after if affirmative. In general, developed countries' AD has a greater negative influence on industrial exports than developing countries'.

[Tables 6-7 around Here]

Generally, most of the estimation results imply that private firms react 
much more than foreign and SOE firms. One reason is that Chinese private firms are the main $\mathrm{AD}$ targets and most of the $\mathrm{AD}$ initiations and measures from abroad are aimed at private firms.

\subsection{Specific Impacts for AD from U.S. and EU}

There is a large difference in the impact of US and EU AD measures. Since US AD measures are aimed at specific firms, but EU AD measures are largely against whole industries, a difference in regime affects country results.

Tables 8 to 9 report US and EU AD estimation results. AD from US and EU have a negative influence on industrial and firm groups' firm numbers, output, employees, profits and exports but have positive effects on labor productivity. $\mathrm{AD}$ from US and EU have more impact than for developed and developing countries, because the US and EU are larger trade partners for China. US AD measures have more influence than EU's on firm numbers, employees and exports; and EU AD measures have more influence than US's on outputs, profits and labor productivity. AD from US and EU have little impact on foreign and SOE firm groups, the same as AD from developed and developing countries. Comparatively, foreign firms are affected more by AD from EU. This may be because EU AD has wider scope and foreign firms in China from the EU are relatively fewer.

Both US and EU variables of year before investigation and measure have a positive influence on all firm numbers. Variables of one year after if more than one investigation from both US and EU and one year after measure from US have significant large negative coefficients, and US's values are bigger than the EU, which mean that all firm numbers react significantly both to US and EU AD and especially to US. Foreign firm numbers have no significant relationship 
with US AD but are significantly related with EU measures. SOE firm numbers have actually no significant relationship with both US and EU AD. Overall, all firm numbers react significantly to both US and EU AD, but foreign and SOE firm numbers react only a little, most of the reaction is by private firms.

Industrial output reacts only a little to both US and EU AD investigations and measures, and EU effects are more. Foreign firm output shows little reaction to AD from US and EU. Both countries' AD measures have negative impacts on SOE firm output, and also EU effects are larger.

AD from US has significant influence on all firm industrial employees, but $\mathrm{AD}$ from $\mathrm{EU}$ has little negative impact. Foreign firm employees respond negatively to AD from both US and EU, and US effects are greater. Generally, foreign firm reactions for employees are smaller than for all firms. SOE firm employees react little. These results also show that US variable of one year after if more than one investigation from both countries has negative influence to SOE firm employees, and also US effect is more intensive. US AD measures seem to have more employee effects than EU.

The variable of one year after if more than one investigation from both countries has significant negative impacts on all firm profits, and EU's influence is much larger. AD from US has little influence on foreign firm profits. But EU's $\mathrm{AD}$ has significant negative impact on foreign firm profits. This may be because the EU is an important export partner for foreign firms. SOE firms' profits show little reaction to $\mathrm{AD}$ from both countries.

AD from both US and EU have labor productivity incentive effects. Variables of one year after measures and one year after if more than one investigation from US and EU separately have positive effects on all firm labor 
productivity, and overall EU effects are bigger than US. Foreign and SOE firm labor productivity show no significant response to AD from both countries.

AD from both US and EU have significantly impacts on industrial exports, and US have more influence. Overall, AD measure impacts on exports are small.

[Tables 8-9 around Here]

\subsection{Robustness Checks of Results}

Our empirical model contains lag terms for dependent variable, and hence endogeneity is a potential problem. Our system GMM method can partly overcome these endogeneity problems. We use two methods to test the validity of the parameter estimates. The first is the Sargan over-identification test to assess the validity of instrumental variables. If this cannot reject the null hypothesis, it suggests that the instrumental variable is appropriate. The second is using an $\operatorname{AR}(2)$ test to check for residual non-autocorrelation, that is testing the existence of second-order residual autocorrelation.

In the empirical results presented in Tables 6-9, all of the $\mathrm{P}$ values for $\mathrm{AR}(2)$ test are bigger than 0.15 , so there would seem to be no residual autocorrelation problem for the estimation. All of the $\mathrm{P}$ values for the Sargan over identification test reveal that instrumental variable selections are appropriate.

In order to further check the robustness of our estimation results we separate AD from developed and developing countries and AD from US and EU to estimate results individually. After comparing the mixed and separate regression results ${ }^{4}$, we find that $\mathrm{AD}$ effects from developed and developing countries, and from US and EU are all the same in both forms of estimation. These feasibility checks suggest that the estimates presented earlier are robust.

\footnotetext{
${ }^{4}$ Mixed estimation results are presented in the Tables 6 to 9. Separate estimation results for robustness checks are omitted in the paper because of the limitation of paper length. Readers interested in these results can contact the authors.
} 


\section{Conclusions and Policy Implications}

In conclusion, our analysis suggests that $\mathrm{AD}$ investigations and measures have significant impact on Chinese industries and firm groups. AD from developed and developing countries including US and EU all reduce firm numbers, output, employee, profit and export, but improve labor productivity. Comparatively, developed countries' AD have more severe impacts than developing countries except for the foreign firm group; and all firm summed industry react the most. Foreign and SOE firm groups just have a little response.

If we take the US and EU as specific country cases, we find that their measures have larger impact than those of other developed and developing countries. Also, US AD measures have more impact on firm numbers, employees and exports; and EU AD measures have more impact on outputs, profits and labor productivity. In addition, AD from both countries have only a small impact on foreign and SOE firm groups. Foreign firm group are relatively affected more by AD from EU.

From these findings, we can assess overall Chinese industrial and firm groups' reactions to AD. They suggest that some Chinese firms have closed down and exited the market under the pressure of $\mathrm{AD}$. When we compare the reaction of output and export, we can see that relocation may be happening since industrial output reacts much more than exports. Firms may also choose to sell more in domestic or export to other countries to avoid the impacts of AD. There is no information to indicate whether producing something else has the reaction, and also we have no data on whether firing against action.

Our results also suggest that Chinese industry and private firm group have been significantly hurt by $\mathrm{AD}$, but exports are comparatively less affected which 
may imply trade diversion. From these results, Chinese industry and firms seemingly might not need to care too much about AD from abroad, but firm profit and return plus employee have been significantly affected by them, which means firms have tried to maintain their exports by reducing costs and prices, so that their trade conditions have deteriorated.

We also show that SOE and foreign firm groups have been less impacted by $\mathrm{AD}$ measures and most of the reactions are by private Chinese firms for they are the main ones targeted. Also Chinese firm groups respond little to AD from developing countries. These results suggest that only main trade partners' AD measures significantly influence Chinese industry and firms. Thus in guarding $\mathrm{AD}$ response China should perhaps emphasize and pay more attention to main trade partner's measures. 


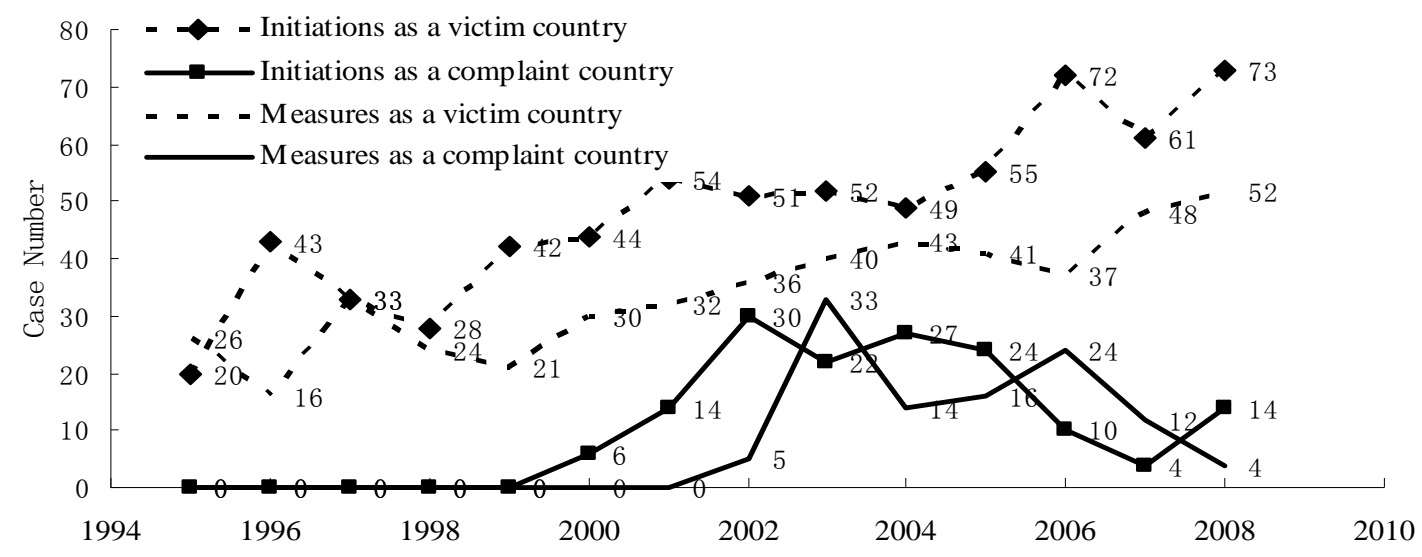

Fig. 1 China’s AD Initiations and Measures, 1995-2008

Source: WTO Antidumping database.

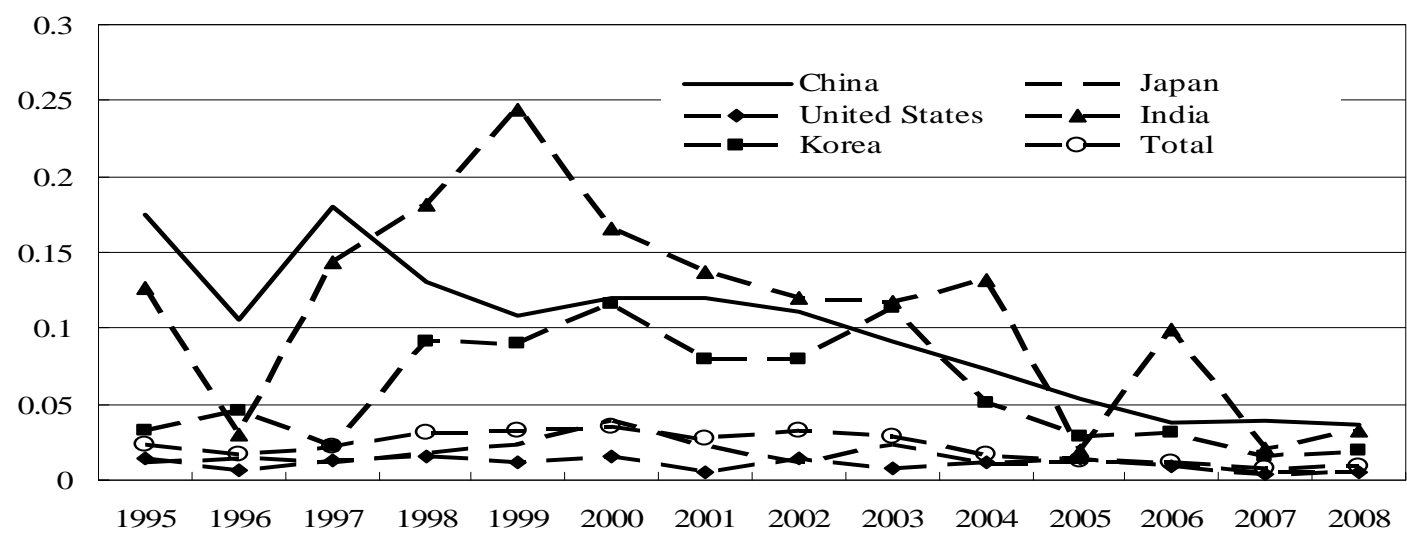

Fig. 2 AD Measures by Export Value over The Period 1995-2008

Unit: Cases per Billions of US Dollar

Sources: AD measures data get from WTO antidumping database; Export value data from United Nations Common Database (UNCD). 
Table 1 Top 10 Global AD Initiation and Measure Recipient Countries over The Period 1995-2008

\begin{tabular}{c|ccc|ccc}
\hline \multirow{2}{*}{ Rank } & \multicolumn{3}{|c|}{ Initiations } & \multicolumn{3}{c}{ Measures } \\
\cline { 2 - 7 } & Country & Amount & Share \% & Country & Amount & Share \% \\
\hline 1 & China & 677 & 19.75 & China & 677 & 19.75 \\
2 & Korea & 252 & 7.35 & Korea & 252 & 7.35 \\
3 & United States & 189 & 5.52 & United States & 189 & 5.52 \\
4 & Chinese Taipei & 187 & 5.46 & Chinese Taipei & 187 & 5.46 \\
5 & Indonesia & 145 & 4.23 & Indonesia & 145 & 4.23 \\
6 & Japan & 144 & 4.20 & Japan & 144 & 4.20 \\
7 & Thailand & 142 & 4.14 & Thailand & 142 & 4.14 \\
8 & India & 137 & 4.00 & India & 137 & 4.00 \\
9 & Russia & 109 & 3.18 & Russia & 109 & 3.18 \\
10 & Brazil & 97 & 2.83 & Brazil & 97 & 2.83 \\
\hline
\end{tabular}

Source: WTO antidumping database.

Table 2 Chinese Total AD Cases Received by Country, 1995-2008

\begin{tabular}{|c|c|c|c|c|}
\hline \multirow[b]{2}{*}{ Country } & \multicolumn{2}{|c|}{ Initiations } & \multicolumn{2}{|c|}{ Measures } \\
\hline & Amount & $\begin{array}{c}\text { Chinese Share in } \\
\text { Total (\%) }\end{array}$ & Amount & $\begin{array}{c}\text { Chinese Share in } \\
\text { Total (\%) }\end{array}$ \\
\hline India & 120 & 17.73 & 90 & 18.11 \\
\hline United States & 87 & 12.85 & 66 & 13.28 \\
\hline European Community & 84 & 12.41 & 60 & 12.07 \\
\hline Argentina & 61 & 9.01 & 40 & 8.05 \\
\hline Turkey & 51 & 7.53 & 48 & 9.66 \\
\hline Brazil & 37 & 5.47 & 21 & 4.23 \\
\hline South Africa & 30 & 4.43 & 16 & 3.22 \\
\hline Australia & 28 & 4.14 & 12 & 2.41 \\
\hline Mexico & 25 & 3.69 & 15 & 3.02 \\
\hline Korea & 23 & 3.40 & 18 & 3.62 \\
\hline Canada & 22 & 3.25 & 15 & 3.02 \\
\hline Columbia & 21 & 3.10 & 11 & 2.21 \\
\hline Peru & 18 & 2.66 & 15 & 3.02 \\
\hline Egypt & 13 & 1.92 & 11 & 2.21 \\
\hline Indonesia & 9 & 1.33 & 5 & 1.01 \\
\hline Venezuela & 9 & 1.33 & 11 & 2.21 \\
\hline others & 39 & 5.76 & 43 & 8.65 \\
\hline All & 677 & 100 & 497 & 100 \\
\hline
\end{tabular}

Source: WTO antidumping database. 
Table 3 Description of Regression Variables

\begin{tabular}{|c|c|c|c|c|}
\hline $\begin{array}{c}\text { Variable } \\
\text { Type }\end{array}$ & Variables & Abbreviate & Description & Source of Data \\
\hline \multirow{6}{*}{$\begin{array}{l}\text { Dependent } \\
\text { Variables } \\
(\mathbf{Y})\end{array}$} & Export & EX & $\begin{array}{l}\text { Total export of a } \\
\text { industry in a year }\end{array}$ & $\begin{array}{c}\text { Chinese Customs Statistic } \\
\text { Yearbook 1997-2008 }\end{array}$ \\
\hline & Output & Output & $\begin{array}{l}\text { Total output of a } \\
\text { industry in a year }\end{array}$ & $\begin{array}{c}\text { Chinese Statistic Yearbook } \\
\text { 1997-2008 }\end{array}$ \\
\hline & Firm Numbers & Firm_no & $\begin{array}{l}\text { Total firm numbers of a } \\
\text { industry in a year }\end{array}$ & $\begin{array}{c}\text { Chinese Statistic Yearbook } \\
\text { 1997-2008 }\end{array}$ \\
\hline & Profit & Profit & $\begin{array}{l}\text { Total profit of a industry } \\
\text { in a year }\end{array}$ & $\begin{array}{c}\text { Chinese Statistic Yearbook } \\
1997-2008\end{array}$ \\
\hline & Employee & Employee & $\begin{array}{l}\text { Total employee of a } \\
\text { industry in a year }\end{array}$ & $\begin{array}{c}\text { Chinese Statistic Yearbook } \\
\text { 1997-2008 }\end{array}$ \\
\hline & Labor Productivity & LP & $\begin{array}{c}\text { Labor productivity of a } \\
\text { industry in a year }\end{array}$ & $\begin{array}{c}\text { Chinese Statistic Yearbook } \\
1997-2008 \\
\end{array}$ \\
\hline \multirow{5}{*}{$\begin{array}{l}\text { Independent } \\
\text { Variables } \\
\text { (Dummy) }\end{array}$} & Year of investigation & $\mathrm{AD}$ & AD investigation year & Global AD Database 2010 \\
\hline & 1 Year after measures & AD1 & $\begin{array}{c}\text { One year later of } \mathrm{AD} \\
\text { measures }\end{array}$ & Global AD Database 2010 \\
\hline & $\begin{array}{l}1 \text { year after if } \\
\text { affirmative }\end{array}$ & $\mathrm{AD} 2$ & $\begin{array}{l}\text { Affirmative AD } 1 \text { year } \\
\text { after measures }\end{array}$ & Global AD Database 2010 \\
\hline & 1 year after if negative & AD3 & $\begin{array}{l}\text { Negative AD } 1 \text { year } \\
\text { after measures }\end{array}$ & Global AD Database 2010 \\
\hline & $\begin{array}{l}1 \text { year after if more } \\
\text { than one investigation }\end{array}$ & $\mathrm{AD} 4$ & $\begin{array}{l}\text { Receive More than } 1 \\
\text { investigation }\end{array}$ & Global AD Database 2010 \\
\hline
\end{tabular}

Source: Compiled by the authors.

Table 4 Overall Summary Statistics For Dependent Variables

\begin{tabular}{lcccccc}
\hline \multicolumn{1}{c}{ Variable } & Unit & Obs. & Mean & Std. Dev. & Min & Max \\
\hline All Firm Summation Sample & & & & & & \\
$\quad$ Export value & RMB100M & 419 & $1.23 \mathrm{E}+07$ & $1.91 \mathrm{E}+07$ & $3.02 \mathrm{E}+05$ & $1.24 \mathrm{E}+08$ \\
$\quad$ Output & RMB100M & 380 & 4236.67 & 5721.39 & 5.20 & 39223.77 \\
Firm number & Entries & 419 & 6245.85 & 6385.44 & 13 & 58662 \\
Employee & 10 Thousand & 419 & 144.21 & 129.18 & 0.08 & 626.26 \\
Profit & RMB100M & 380 & 262.35 & 447.77 & -312.24 & 3652.12 \\
Ln(lp) & $100 \mathrm{M} /$ Person & 419 & 5.79 & 2.51 & -7.25 & 10.55 \\
Foreign Firm Summation Sample & & & & & & \\
Export value & RMB100M & 0 & & & & \\
Output & RMB100M & 337 & 1383.65 & 3040.62 & 0.01 & 32966.71 \\
Firm number & Entries & 375 & 1133.57 & 1229.53 & 1 & 6047 \\
Employee & 10 Thousand & 193 & 47.02 & 64.41 & 0.01 & 442.72 \\
Profit & RMB100M & 336 & 84.91 & 142.91 & -1.94 & 1114.47 \\
Ln(lp) & $100 \mathrm{M} /$ Person & 193 & 2.81 & 4.02 & -13.46 & 9.97 \\
SOE Firm Summation Sample & & & & & & \\
Export value & RMB100M & 0 & & & & \\
Output & RMB100M & 343 & 1591.52 & 2816.04 & 0.14 & 24025.61 \\
Firm number & Entries & 382 & 1083.47 & 1196.93 & 1 & 8057 \\
Employee & 10 Thousand & 195 & 49.40 & 65.78 & 0.01 & 335.30 \\
Profit & RMB100M & 342 & 126.95 & 382.13 & -417.89 & 3642.23 \\
Ln(lp) & $100 \mathrm{M} /$ Person & 195 & 3.09 & 3.87 & -13.83 & 9.53 \\
\hline & & & & & &
\end{tabular}


Table 5 Overall Summary Statistics For the Independent Variables

\begin{tabular}{|c|c|c|c|c|c|}
\hline Variable & Obs. & Mean & Std. Dev. & Min & Max \\
\hline \multicolumn{6}{|l|}{ AD from Developed Countries } \\
\hline Year of AD Investigation & 419 & 0.1838 & 0.3878 & 0 & 1 \\
\hline 1 Year After if Affirmative & 419 & 0.1098 & 0.3130 & 0 & 1 \\
\hline 1 Year After if Negative & 419 & 0.0621 & 0.2415 & 0 & 1 \\
\hline 1 Year After if More than One Investigation & 419 & 0.0501 & 0.2185 & 0 & 1 \\
\hline 1 Year After AD Measure & 419 & 0.1742 & 0.3798 & 0 & 1 \\
\hline \multicolumn{6}{|l|}{ AD from Developing Countries } \\
\hline Year of AD Investigation & 419 & 0.2148 & 0.4112 & 0 & 1 \\
\hline 1 Year After if Affirmative & 419 & 0.1146 & 0.3189 & 0 & 1 \\
\hline 1 Year After if Negative & 419 & 0.0692 & 0.2541 & 0 & 1 \\
\hline 1 Year After if More than One Investigation & 419 & 0.0549 & 0.2280 & 0 & 1 \\
\hline 1 Year After AD Measure & 419 & 0.1814 & 0.3858 & 0 & 1 \\
\hline \multicolumn{6}{|l|}{ AD from US } \\
\hline Year of AD Investigation & 419 & 0.1098 & 0.3130 & 0 & 1 \\
\hline 1 Year After if Affirmative & 419 & 0.0931 & 0.2909 & 0 & 1 \\
\hline 1 Year After if Negative & 419 & 0.0167 & 0.1283 & 0 & 1 \\
\hline 1 Year After if More than One Investigation & 419 & 0.0191 & 0.1370 & 0 & 1 \\
\hline 1 Year After AD Measure & 419 & 0.1026 & 0.3038 & 0 & 1 \\
\hline \multicolumn{6}{|l|}{ AD from EU } \\
\hline Year of AD Investigation & 419 & 0.1026 & 0.3038 & 0 & 1 \\
\hline 1 Year After if Affirmative & 419 & 0.0644 & 0.2458 & 0 & 1 \\
\hline 1 Year After if Negative & 419 & 0.0215 & 0.1452 & 0 & 1 \\
\hline 1 Year After if More than One Investigation & 419 & 0.0191 & 0.1370 & 0 & 1 \\
\hline 1 Year After AD Measure & 419 & 0.0859 & 0.2806 & 0 & 1 \\
\hline
\end{tabular}


Table 6 Effects of Developed and Developing Countries’ AD Measures on Chinese Industry I (GMM- System Regression)

\begin{tabular}{|c|c|c|c|c|c|c|c|c|c|}
\hline \multirow{2}{*}{ Dependent Variable: $\ln (\mathrm{Y})$} & \multicolumn{3}{|c|}{ Firm Number } & \multicolumn{3}{|c|}{ Industry Output } & \multicolumn{3}{|c|}{ Industry Employee } \\
\hline & All Firm & Foreign Firm & SOE Firm & All Firm & Foreign Firm & SOE Firm & All Firm & Foreign Firm & SOE Firm \\
\hline $\ln (\mathrm{Y})(-1)$ & $0.660 * * *$ & $0.973^{* * *}$ & $1.020 * * *$ & $0.717 * * *$ & $0.942 * * *$ & $1.042 * * *$ & $0.893 * * *$ & $0.900 * * *$ & $1.005^{* * *}$ \\
\hline \multicolumn{10}{|l|}{ AD from Developed Countries } \\
\hline 1 year before investigation & $0.243^{* * *}$ & 0.0151 & $-0.0322 * *$ & $0.139 * *$ & 0.0175 & -0.0218 & $0.0947 *$ & -0.135 & -0.0124 \\
\hline Year of investigation & $0.305^{* * *}$ & 0.0178 & -0.0234 & $0.118 * *$ & 0.0505 & 0.00442 & 0.0562 & -0.163 & 0.0462 \\
\hline Year of measures & $0.230 * * *$ & 0.0181 & -0.00803 & $0.153^{* * *}$ & -0.00583 & $-0.0672 * *$ & 0.0112 & -0.0608 & -0.0269 \\
\hline 1 year after if affirmative & & & 0.00764 & 0.174 & 1.868 & 2.951 & $-0.402 *$ & $-1.329 *$ & 0.194 \\
\hline 1 year after if negative & $0.918 * * *$ & 0.0992 & 0.0414 & 0.0560 & -1.819 & -2.427 & -0.118 & $2.827 *$ & -0.0205 \\
\hline 1 year after if more than one investigation & $-0.0164^{* *}$ & $-0.137 *$ & -0.0466 & $-0.0743^{*}$ & 0.0618 & $-0.153^{* * *}$ & 0.0361 & 0.417 & -0.0140 \\
\hline 1 year after measures & $-0.212 *$ & -0.243 & -0.0520 & $-0.150 * *$ & -1.902 & -2.988 & -0.350 & -1.332 & -0.252 \\
\hline 1 year after measures*1 year after if affirmative & $-0.00541^{*}$ & $-0.281 *$ & & & & & & & \\
\hline 1 year after measures* 1 year after if negative & -0.944 & 0.170 & -0.0147 & 0.169 & 3.740 & 5.406 & 0.434 & 4.331* & 0.134 \\
\hline 1 year after measures* after if more than ones & -0.0234 & 0.0719 & 0.0830 & 0.114 & -0.0382 & -0.179 & -0.0574 & $-0.438 * *$ & $-0.162 *$ \\
\hline \multicolumn{10}{|l|}{ AD from Developing Countries } \\
\hline 1 year before investigation & $0.178 * * *$ & 0.0255 & -0.00419 & $0.0623 * *$ & -0.0180 & 0.0292 & $0.0757 *$ & -0.00165 & -0.0974 \\
\hline Year of investigation & $0.205^{* * *}$ & 0.00998 & -0.0143 & $0.0836^{*}$ & 0.00524 & $0.0674 * *$ & $0.119 * * *$ & -0.0118 & -0.0386 \\
\hline Year of measures & 0.0793* & $-0.0368 *$ & -0.00848 & 0.0434 & 0.0227 & -0.00808 & -0.0234 & -0.0202 & $-0.0582^{*}$ \\
\hline 1 year after if affirmative & $-0.235^{* * *}$ & -0.0419 & 0.000163 & 0.0296 & 0.0262 & -0.125 & 0.0268 & $-0.178 * *$ & -0.0158 \\
\hline 1 year after if negative & $0.299 * * *$ & -0.0156 & 0.0561* & -0.111 & 0.0505 & 0.0392 & -0.139 & 0.0714 & \\
\hline 1 year after if more than one investigation & 0.400 & $-0.282 *$ & -0.374 & 0.297 & -2.158 & -3.149 & -0.684 & $-1.548 *$ & 0.0947 \\
\hline 1 year after measures & $0.162 * *$ & 0.0113 & -0.0101 & $-0.128 * *$ & 0.0559 & $-0.129 * *$ & $0.0660 *$ & -0.0788 & -0.00730 \\
\hline 1 year after measures* 1 year after if affirmative & $-0.199 *$ & 0.0444 & $-0.0436 *$ & $-0.0512 *$ & -0.0792 & 0.202 & 0.0881 & $-0.176 *$ & -0.0286 \\
\hline 1 year after measures* 1 year after if negative & $0.334 * * *$ & 0.0514 & -0.0850 & 0.0594 & 0.0119 & 0.0124 & 0.191 & & -0.0859 \\
\hline 1 year after measures* after if more than ones & -0.366 & $-0.322 *$ & 0.372 & -0.401 & 2.178 & 3.160 & 0.734 & 1.608 & -0.0451 \\
\hline Time & $0.0540 * * *$ & $0.0204^{* * *}$ & 0.00111 & $0.0607 * * *$ & $0.0339 * * *$ & $0.0230 *$ & $0.0292 * * *$ & 0.0372* & 0.0149 \\
\hline Cons. & $-105.7 * * *$ & $-40.67 * * *$ & -2.437 & $-120.8^{* * *}$ & $-67.75^{* * *}$ & $-46.02 *$ & $-58.00 * * *$ & $-74.11 *$ & -29.81 \\
\hline Obs. & 378 & 296 & 304 & 300 & 220 & 226 & 378 & 154 & 156 \\
\hline AR(2)-P value & 0.9981 & 0.5618 & 0.4587 & 0.8832 & 0.4251 & 0.968 & 0.2713 & 0.2385 & 0.3035 \\
\hline Sargan test-P value & 0.1621 & 0.1721 & 0.1849 & 0.1880 & 0.3218 & 0.3575 & 0.2747 & 0.1647 & 0.1910 \\
\hline
\end{tabular}

Note: $* * *, * * *$ denote significantly different from zero at $10 \%, 5 \%$ and $1 \%$ confidence level. 
Table 7 Effects of Developed and Developing Country AD Measures on Chinese Industry II (GMM- System Regression)

\begin{tabular}{|c|c|c|c|c|c|c|c|}
\hline \multirow{2}{*}{ Dependent Variable: $\ln (Y)$} & \multicolumn{3}{|c|}{ Industry Profit } & \multicolumn{3}{|c|}{ Labor Productivity } & \multirow{2}{*}{$\begin{array}{c}\text { Industry Export } \\
\text { All Firm }\end{array}$} \\
\hline & All Firm & Foreign Firm & SOE Firm & All Firm & Foreign Firm & SOE Firm & \\
\hline $\ln (\mathrm{Y})(-1)$ & $0.870^{* * *}$ & $0.647^{* * *}$ & $0.669 * * *$ & $0.682 * * *$ & $0.797 * * *$ & $0.695 * * *$ & $0.720 * * *$ \\
\hline \multicolumn{8}{|l|}{ AD from Developed Countries } \\
\hline 1 year before investigation & -0.0648 & -0.0283 & 0.117 & $0.373^{* * *}$ & $1.024 * *$ & 0.205 & 0.0221 \\
\hline Year of investigation & $-0.0992 *$ & -0.0491 & 0.133 & 0.212 & 0.639 & -0.505 & 0.0332 \\
\hline Year of measures & $-0.184 * * *$ & $-0.124 *$ & -0.114 & 0.202 & 0.432 & -0.550 & $-0.110^{*}$ \\
\hline 1 year after if affirmative & -0.0890 & -0.276 & & 0.447 & -3.659 & 0.248 & $-0.130 *$ \\
\hline 1 year after if negative & 1.211 & -0.143 & 2.555 & -0.307 & $3.837 *$ & 0.771 & -0.127 \\
\hline 1 year after if more than one investigation & $-1.110 *$ & $0.415^{*}$ & 0.131 & 0.292 & 0.108 & -0.567 & 0.0161 \\
\hline 1 year after measures & $-0.0134 *$ & 0.141 & 0.330 & -0.690 & 3.020 & -1.375 & 0.167 \\
\hline 1 year after measures*1 year after if affirmative & & & -0.447 & & & & \\
\hline 1 year after measures*1 year after if negative & -1.327 & -0.118 & -3.233 & 0.793 & $7.702 *$ & -0.510 & \\
\hline 1 year after measures* after if more than ones & 0.962 & $-0.401 * *$ & -0.0708 & 0.758 & $-1.654^{* *}$ & $1.897 * * *$ & \\
\hline \multicolumn{8}{|l|}{ AD from Developing Countries } \\
\hline 1 year before investigation & $0.0924 *$ & 0.103 & 0.113 & $0.243^{*}$ & -0.382 & $-0.670 *$ & 0.0727 \\
\hline Year of investigation & 0.0788* & $0.266^{* * *}$ & 0.0200 & $0.355^{* * *}$ & 0.215 & 0.138 & 0.00770 \\
\hline Year of measures & $0.0900 * *$ & $0.153^{* * *}$ & 0.0642 & $0.391 * * *$ & 0.0841 & 0.244 & $-0.0615 * * *$ \\
\hline 1 year after if affirmative & -0.0615 & -0.0246 & 0.0926 & -0.0838 & 0.307 & 0.226 & $-0.00751 * *$ \\
\hline 1 year after if negative & 0.0774 & -0.543 & -0.0159 & -0.247 & -0.829 & & -0.406 \\
\hline 1 year after if more than one investigation & -0.00451 & 0.839 & 0.721 & 2.716 & $11.93^{* *}$ & 0.569 & 0.240 \\
\hline 1 year after measures & -0.0515 & -0.481 & $0.657 * *$ & $0.557 * * *$ & 1.116 & $1.131 *$ & 0.0336 \\
\hline 1 year after measures*1 year after if affirmative & $-0.197^{*}$ & $-0.616 * *$ & $-0.612 *$ & 0.123 & -0.701 & -0.481 & -0.0538 \\
\hline 1 year after measures*1 year after if negative & -0.0211 & 1.088 & -0.291 & 0.307 & & -0.780 & 0.314 \\
\hline 1 year after measures* after if more than ones & $-0.0901 *$ & -0.887 & -1.050 & -3.324 & -12.69 & -1.710 & \\
\hline Time & $0.0178^{* * *}$ & $0.0865 * * *$ & 0.0417 & $0.0907^{* * *}$ & $-0.203^{* * *}$ & $-0.232 * * *$ & $0.0636^{*}$ \\
\hline Cons. & $-35.32 * * *$ & $-173.8 * * *$ & -83.97 & $-180.2 * * *$ & $406.8 * * *$ & $466.8 * * *$ & $-124.5 *$ \\
\hline Obs. & 323 & 291 & 255 & 378 & 154 & 156 & 184 \\
\hline AR(2)-P value & 0.7771 & 0.4859 & 0.1755 & 0.2125 & 0.1829 & 0.9429 & 0.5205 \\
\hline Sargan test-P value & 0.6879 & 0.7297 & 0.2702 & 0.1251 & 0.1628 & 0.1703 & 0.9864 \\
\hline
\end{tabular}

Note: $*, * *, * * *$ denote significantly different from zero at $10 \%, 5 \%$ and $1 \%$ confidence level. 
Table 8 Effects of US and EU AD Measures on Chinese Industry I (GMM- System Regression)

\begin{tabular}{|c|c|c|c|c|c|c|c|c|c|}
\hline \multirow{2}{*}{ Dependent Variable: $\ln (\mathrm{Y})$} & \multicolumn{3}{|c|}{ Firm Number } & \multicolumn{3}{|c|}{ Industry Output } & \multicolumn{3}{|c|}{ Industry Employee } \\
\hline & All Firm & Foreign Firm & SOE Firm & All Firm & Foreign Firm & SOE Firm & All Firm & Foreign Firm & SOE Firm \\
\hline $\ln (\mathrm{Y})(-1)$ & $0.655^{* * *}$ & $0.974 * * *$ & $1.018 * * *$ & $0.747 * * *$ & $0.955^{* * *}$ & $1.035^{* * *}$ & $0.904 * * *$ & $0.849 * * *$ & $0.993^{* * *}$ \\
\hline \multicolumn{10}{|l|}{ AD from US } \\
\hline 1 year before investigation & $0.207 * * *$ & 0.0115 & $-0.0412 * * *$ & 0.0817 & 0.00159 & 0.0230 & 0.0583* & 0.0626 & -0.0257 \\
\hline Year of investigation & $0.338 * * *$ & 0.0360 & -0.0268 & $0.125^{* *}$ & 0.0508 & $0.0583^{* *}$ & $0.136 * * *$ & 0.0432 & 0.000706 \\
\hline Year of measures & $0.251 * * *$ & 0.0149 & $-0.0314^{* *}$ & $0.116 * *$ & $-0.0681^{*}$ & -0.0115 & $0.0817 *$ & $0.141^{*}$ & 0.0183 \\
\hline 1 year after if affirmative & -0.405 & -0.113 & & $-0.0279 *$ & -0.0590 & $-0.233^{* * *}$ & $-0.184 *$ & & 0.219 \\
\hline 1 year after if negative & -0.260 & -0.128 & -0.0332 & -0.00829 & -0.0571 & $0.0775^{* * *}$ & $0.255^{* * *}$ & -0.261 & 0.0337 \\
\hline 1 year after if more than one investigation & $-0.133 *$ & 0.00513 & -0.0363 & 0.00814 & -0.00873 & -0.0302 & $-0.194 * * *$ & $-0.162 *$ & $-0.0334 *$ \\
\hline 1 year after measures & $-0.602 *$ & 0.143 & -0.0218 & 0.121 & 0.0546 & $-0.204 * * *$ & $-0.250 * *$ & 0.0932 & -0.215 \\
\hline \multicolumn{10}{|l|}{1 year after measures* 1 year after if affirmative } \\
\hline 1 year after measures*1 year after if negative & & & 0.0278 & & & & & 0.125 & \\
\hline \multicolumn{10}{|l|}{1 year after measures* after if more than ones } \\
\hline \multicolumn{10}{|l|}{ AD from EU } \\
\hline 1 year before investigation & $0.250 * * *$ & $0.0925^{* * *}$ & 0.0145 & $0.133^{* * *}$ & $0.109 * *$ & 0.0256 & $0.178^{* * *}$ & 0.108* & 0.0227 \\
\hline Year of investigation & $0.288 * * *$ & 0.0135 & 0.0138 & 0.00919 & $0.0799 * *$ & 0.0276 & $0.0642 *$ & 0.0156 & -0.0602 \\
\hline Year of measures & $0.249 * * *$ & $0.0516 * *$ & 0.0128 & 0.0589 & 0.0525 & 0.0109 & 0.0352 & 0.0976* & 0.00933 \\
\hline 1 year after if affirmative & -0.577 & $-0.157 * *$ & 0.0417 & $-0.328 *$ & 0.184 & $-0.224 * * *$ & 0.0363 & $-0.0355^{*}$ & 0.0167 \\
\hline 1 year after if negative & -0.660 & $0.210 * * *$ & 0.0665 & -0.301 & 0.131 & $0.263 * * *$ & -0.0352 & 0.170 & -0.0341 \\
\hline 1 year after if more than one investigation & $-0.101 *$ & -0.0471 & -0.0130 & -0.0269 & -0.0518 & 0.0455 & -0.0486 & $-0.201 *$ & $-0.00662 *$ \\
\hline 1 year after measures & 0.725 & $-0.168 * * *$ & -0.0357 & 0.303 & -0.132 & $-0.257 * * *$ & -0.0742 & 0.00596 & -0.0434 \\
\hline \multicolumn{10}{|l|}{1 year after measures* 1 year after if affirmative } \\
\hline \multicolumn{10}{|l|}{1 year after measures* 1 year after if negative } \\
\hline \multicolumn{10}{|l|}{1 year after measures* after if more than ones } \\
\hline Time & $0.0626 * * *$ & $0.0175^{* * *}$ & $-0.00313^{*}$ & $0.0549 * * *$ & $0.0411 * * *$ & 0.0199* & $0.0277^{* * *}$ & 0.0144 & 0.0131* \\
\hline cons & $-122.8 * * *$ & $-34.77 * * *$ & 6.033* & $-109.3^{* * *}$ & $-82.17 * * *$ & $-39.79 *$ & $-55.18 * * *$ & -28.36 & $-26.42 *$ \\
\hline Obs. & 378 & 296 & 304 & 300 & 220 & 226 & 378 & 154 & 156 \\
\hline AR(2)-P value & 0.8323 & 0.4517 & 0.4494 & 0.3938 & 0.4806 & 0.8667 & 0.5501 & 0.2224 & 0.3111 \\
\hline Sargan test-P value & 0.1163 & 0.1652 & 0.1783 & 0.1759 & 0.1783 & 0.2171 & 0.1027 & 0.1612 & 0.1551 \\
\hline
\end{tabular}

Note: ${ }^{*},{ }^{* *},{ }^{* * *}$ denote significantly different from zero at $10 \%, 5 \%$ and $1 \%$ confidence level. 
Table 9 Effects of US and EU AD Measures on Chinese Industry II (GMM- System Regression)

\begin{tabular}{|c|c|c|c|c|c|c|c|}
\hline \multirow{2}{*}{ Dependent Variable: $\ln (\mathrm{Y})$} & \multicolumn{3}{|c|}{ Industry Profit } & \multicolumn{3}{|c|}{ Labor Productivity } & \multirow{2}{*}{$\begin{array}{c}\text { Industry Export } \\
\text { All Firm }\end{array}$} \\
\hline & All Firm & Foreign Firm & SOE Firm & All Firm & Foreign Firm & SOE Firm & \\
\hline $\operatorname{Ln}(Y)(-1)$ & $0.849 * * *$ & $0.653^{* * *}$ & $0.580 * * *$ & $0.725 * * *$ & $0.820 * * *$ & $0.669 * * *$ & $1.030 * * *$ \\
\hline \multicolumn{8}{|l|}{ AD from US } \\
\hline 1 year before investigation & $-0.0989 * * *$ & -0.0835 & $0.152 *$ & $0.242 * * *$ & $0.915 *$ & $0.877^{*}$ & $0.0852 * *$ \\
\hline Year of investigation & -0.00405 & $-0.135 *$ & 0.199 & $0.503^{* * *}$ & 0.676 & 0.531 & $0.107 *$ \\
\hline Year of measures & 0.0380 & -0.0350 & -0.0362 & $0.538 * * *$ & 0.732 & 0.860 & 0.0202 \\
\hline 1 year after if affirmative & & 0.154 & & -0.429 & & 1.235 & \\
\hline 1 year after if negative & 0.181 & 0.0697 & $0.799 * * *$ & $-0.414^{*}$ & 0.0326 & 0.445 & -0.264 \\
\hline 1 year after if more than one investigation & $-0.0626^{*}$ & -0.157 & 0.0385 & $0.616 * * *$ & 0.233 & 0.161 & 0.0208 \\
\hline 1 year after measures & 0.00858 & -0.130 & 0.0934 & 0.774* & -0.219 & -1.240 & $-0.0628 *$ \\
\hline $\begin{array}{l}1 \text { year after measures*1 year after if affirmative } \\
1 \text { year after measures*1 year after if negative } \\
1 \text { year after measures* after if more than ones }\end{array}$ & $-0.313^{* *}$ & & $-1.060 * * *$ & & 0.556 & & $-0.338 *$ \\
\hline \multicolumn{8}{|l|}{ AD from $E U$} \\
\hline 1 year before investigation & $0.141 * * *$ & -0.0808 & 0.0479 & $0.287 * *$ & -0.734 & $-0.842 *$ & 0.0359 \\
\hline Year of investigation & $0.199 * * *$ & -0.0853 & 0.154 & $0.273^{*}$ & 0.124 & -0.465 & -0.0434 \\
\hline Year of measures & 0.0316 & -0.0771 & 0.211 & 0.111 & -0.0965 & -0.462 & 0.0491 \\
\hline 1 year after if affirmative & -0.446 & $-0.407^{*}$ & 0.0826 & $-1.396^{* *}$ & -1.478 & -1.437 & -0.0928 \\
\hline 1 year after if negative & -0.542 & $0.509 *$ & -0.0601 & -1.501 & $-2.269 *$ & -2.477 & \\
\hline 1 year after if more than one investigation & $-0.163 * * *$ & 0.0589 & 0.0920 & $0.370 * * *$ & 0.916 & 0.553 & $-0.0424 *$ \\
\hline 1 year after measures & 0.398 & $-0.635 * *$ & 0.123 & $1.278 *$ & 2.072 & 1.694 & $-0.0460 *$ \\
\hline $\begin{array}{l}1 \text { year after measures*1 year after if affirmative } \\
1 \text { year after measures*1 year after if negative } \\
1 \text { year after measures* after if more than ones }\end{array}$ & & & & & & & \\
\hline Time & $0.0203^{* * *}$ & $0.0944^{* * *}$ & $0.0883 * * *$ & $0.0854 * * *$ & $-0.135^{* * *}$ & $-0.244 * * *$ & 0.00854 \\
\hline cons & $-40.44 * * *$ & $-189.4^{* * *}$ & $-177.5^{* * *}$ & $-169.5^{* * *}$ & $272.3^{* * *}$ & $491.2 * * *$ & -17.26 \\
\hline Obs. & 323 & 291 & 255 & 378 & 154 & 156 & 184 \\
\hline AR(2)-P value & 0.7961 & 0.4295 & 0.2196 & 0.1991 & 0.5360 & 0.8016 & 0.3393 \\
\hline Sargan test-P value & 0.1689 & 0.3738 & 0.1431 & 0.1625 & 0.1501 & 0.1523 & 0.4356 \\
\hline
\end{tabular}

Note: $*, * *, * * *$ denote significantly different from zero at $10 \%, 5 \%$ and $1 \%$ confidence level. 


\section{References}

Arellano, M. and S. Bond. 1991. "Some Tests of Specification for Panel Data: Monte Carlo Evidence and An Application to Employment Equations". Review of Economic Studies, 58, pp.277-297.

Arellano, M. and O. Bover. 1995. "Another Look at the Instrumental-variable Estimation of Error Components Models". Journal of econometrics, 68, pp.29-52.

Baylis, K., N. Malhotra and H. Rus. 2009. "The Effect of AD in Agriculture: A Cross-Border Comparison". University of Illinois Working Paper, July 7.

Blundell, R. W. and S. R. Bond. 1998. "Initial Conditions and Moment Restrictions in Dynamic Panel Data Models". Journal of International Econometrics, 87, pp.115-143.

Bown, C. P. 2010. "Global AD Database". World Bank Working Paper No.3737, Available at http://econ.worldbank.org/ttbd/gad/.

Bown, C.P. and M.A. Crowley. 2010. "China's Export Growth and the China Safeguard". World Bank Policy Research Working Paper No.5291, May.

Brown, A. C. 2005. "How to Respond to AD Duties? Korea, United States, and the Rest of the World". The Ohio State University Working Paper, May 26.

Carter, C. A. and C. G. Trant. 2010. "US Trade Remedy Law and Agriculture: Trade Diversion and Investigation Effects". Canadian Journal of Economics, 43(1), pp.97-126.

Chen, R. 2009. "On China's Non Market Economy Status in Antidumping". Global IPRS Research Center Paper,

Chu, T. and T. Prusa. 2004. "The Reasons for and the Impact of Antidumping Protection: The Case of People's Republic of China". East-West Centre Working Papers.

Crowley, M. A. 2006. "Do Safeguard Tariff and AD Duties Open or Close Technology Gaps". Journal of International Economics, 68, pp.469-484.

Duc, N. M. 2010. "Application of Econometric Models for Price Impact Assessment of AD Measures and Labeling Laws on Global Markets: a Case Study of Vietnamese Striped Catfish". Reviews in Aquaculture, 2, pp.86-101.

Francois, J. 2009. "An Extended Global Simulation Model: Analysis of Tariffs \& Anti-dumping Policy Impacts on Prices, Output, Incomes, and Employment". Institute for International and Development economics Report 200908-03, August.

Ganguli, B. 2005. "The Trade Effects of Indian AD Actions". The State University of New Jersey Working Paper, October 26.

Hendry, D.F. and M.P. Clements. 2004. "Pooling of Forecasts". Econometrics Journal, 7, pp.1-31.

Konings J. and H. Vandenbussche. 2005. "AD Protection and Markups of Domestic Firms". Journal of International Economics, 65, pp.151-165.

Konings J. and H. Vandenbussche. 2008a. "AD Protection and Exports: Firm-level Evidence". Catholic University of Leuven Working Paper, September.

Konings J. and H. Vandenbussche. 2008b. "Heterogeneous Responses of Firms to Trade Protection". Journal of International Economics, 76(2), pp.371-383.

Konings J. and H. Vandenbussche. 2009. "AD Protection Hurts Exporters: Firm-Level Evidence From France". CEPR Discussion Paper No. 7330.

McGee, R.W. and Y. Yoon. 1998. "Antidumping and the People's Republic of China: Five Case Studies". Working Paper, May.

Messerlin, P.A. 2004. "China in the World Trade Organization: Antidumping and Safeguards". The World Bank Economic Review, 18(1), pp.105-130.

Park, S. 2009. "The Trade Depressing and Trade Diversion Effect of AD Actions: The Case of China". China economic Review, 20, pp.542-548.

Pierce, J. R. 2009. "Plant-level Responses to AD Duties: evidence from U.S. Manufacturers". Center for Economic Studies (CES) Research Paper 09-38, October.

Prusa, T. J. 2001. "On the Spread and Impact of AD". The Canadian Journal of Economics, 34(3), pp.591-611.

Staiger, R. W. and F. A. Wolak. 1994. "Measuring Industry-specific Protection: AD in the United States". Brookings Papers on Economic Activity, Microeconomics, Vol.1994, pp.51-118.

Windmeijer, F. 2005. "A Finite Sample Correction for the Variance of Linear Efficient Two-step GMM Estimators". Journal of Econometrics, 126, pp.25-51.

WTO. 2010. "WTO AD Database". http://www.wto.org/english/tratop_e/adp_e/adp_e.htm. 